ISSN 2746-2439 (Print)

ISSN xxxx-Xxxx (Online)

\title{
The Effect Of Discipline, Motivation And Satisfaction On Employee Performance In Hotels
}

\author{
Andi Wijaya ${ }^{1}$, Agustin $\mathrm{HP}^{2}$ \\ Student STIE Mandala Jember ${ }^{1}$, Lecturer, STIE Mandala Jember ${ }^{2}$, \\ Email: agustin@stie-mandala.ac.id ${ }^{2}$
}

\begin{abstract}
One concept to maintain corporate image is employee performance. A concept that seeks to create a good and reliable Human Resources within the company to achieve the goals of the company itself. When the company has committed to maintain employee performance improvement will encourage companies to pay attention to the level of work discipline experienced by employees and the provision of proper work motivation to see the level of job satisfaction of each employee will make employees feel more eager in completing the work. The population of this study were non-permanent employees of Hotel ASTON Jember and the sample was set by 50 respondents. The variables analyzed in this research are work discipline, work motivation and job satisfaction as independent variable, and employee performance as dependent variable. The sampling method used is simple random Sampling in which all permanent employees have the opportunity to be sampled in this study. This type of research is an explanatory research.Research is a study that tries to explain a subject matter and there is a hypothesis testing and perform analysis of data obtained. Methods of data analysis using Multiple Linear Regression Analysis. The results of this study indicate that discipline, motivation and satisfaction simultaneously have a positive and significant effect on employee performance at Hotel ASTON Jember, partially work discipline has a positive and significant impact on employee performance at Hotel ASTON Jember, partially motivation of work has a positive and significant impact on performance Employees at Hotel ASTON Jember and job satisfaction have a negative and insignificant effect on the performance of Hotel ASTON Jember's employees.
\end{abstract}

Keywords: Discipline, Motivation, Satisfaction, Performance 


\section{INTRODUCTION}

Improved employee performance will bring progress for the company to be able to survive in an unstable business environment competition. Therefore, efforts to improve employee performance are the most serious management challenges because the success in achieving goals and the survival of the company depends on the quality of performance According to Aritonang (2005), employees work discipline is part of the performance factor. Work discipline must be owned by every employee and must be cultivated among employees in order to support the achievement of organizational goals because it is a manifestation of compliance with work rules and also as self-responsibility towards the company, the implementation of discipline based on awareness and conviction of creating a harmonious condition between desires and reality.

According to Mathis and Jackson (2006: 114) motivation is a desire in a person that causes that person to act. People act usually for a reason to achieve a goal. According to Sunyoto (2012: 11) motivation is an impulse that grows in a person. Both from within and from outside himself to do a job with high enthusiasm using all the abilities and skills he has in order to achieve organizational goals.

Employees are a very valuable company asset that must be managed properly by the company in order to contribute optimally. One of the things that must be the main concern of the company is job satisfaction of its employees, because employees who at work they do not feel comfortable, are not appreciated, cannot develop all their potential, so employees automatically cannot focus and concentrate fully on their work. . Employee job satisfaction according to Hariadja (2002: 291) can be seen that "work is not just doing work, but also related to other aspects such as interacting with colleagues, superiors, following certain rules and work environments that are often inadequate or lacking. liked "

Job satisfaction is basically an individual thing, each individual has a different level of job satisfaction according to his wishes and the value system he adopts (Handoko, 2000: 192). The more aspects of the job that are in accordance with the wishes and value systems of the individual, the higher the level of satisfaction obtained. Likewise, the more aspects of the job that are not in accordance with the wishes and value systems adopted by the individual, the lower the level of satisfaction obtained. Job satisfaction is a pleasant emotional state with how workers perceive their work. 
Thus the problem that can be formulated is how ordinary management improves the performance of its employees with various variables that influence it.

\section{RESEARCH METHODS}

\section{Object of research}

In this study, the object used as research is ASTON Hotel Jember, which has its address at Jalan Sentot Prawirodirjo No. 88 Jember. This object will explain the influence of discipline, motivation and satisfaction on employee performance.

\section{Population and Sample}

The population that becomes the object of this research is the temporary employees or dailymworkers at the Hotel ASTON Jember with a total of 50 permanent employees. Based on these considerations, this study uses the census method, which is to use all existing populations because the total population does not reach 100 .So, the number of samples in this study were 50 respondents consisting of daily workers or non-permanent employees at Hotel ASTON Jember.

\section{Data analysis method}

Validity test

The validity test aims to determine the validity of the data obtained from distributing questionnaires. The validity test as a measuring tool in this study uses Pearson's product moment correlation, which is by correlating each question with the total score, then the correlation results are compared with the critical number at a significant level of 5\%, using the formula (Prayitno, 2010: 90)

\section{Reliability Test}

The reliability test is used to test the ability of a measurement result to be relatively consistent if the measurement is repeated two or more times (Priyatno, 2010: 97). Reliability concentrates on the problem of measurement accuracy and its results. In other words, reliability shows how much control measures the same subject is. Testing the constraints of measuring instruments in research tools using the reliability of the alpha (a) method used is the Cronbach method, namely (Priyatno, 2010: 97). Reliability measurement is done by 
testing the cronbach Alpha statistic. A variable is performed reliably if the variable provides a Cronbach Alpha value> 0.60

Multiple Linear Regression Analysis

To determine the effect of work discipline and work motivation on employee performance at Hotel Bintang Mulia \& Resto Jember, multiple linear regression analysis was used (Priyatno, 2010: 124):

$\mathrm{Y}=\mathrm{a}+\mathrm{b} 1 \mathrm{X} 1+\mathrm{b} 2 \mathrm{X} 2+\mathrm{b} 3 \mathrm{X} 3+\mathrm{e}$

\section{Classic assumption test}

After obtaining a multiple linear regression model, the next step is to take whether the model developed is BLUE (Best Linear Unbised Estimator). This method has a criterion that observations must represent minimum variation, be constant, and are efficient. The BLUE assumptions that must be fulfilled include: no multicollinearity, no heteroscedasticity and normally distributed data.

Normality test

The data normality test is carried out to determine whether the data obtained is normally distributed or not. The normality test carried out on the sample was carried out using the Kolmogorov-Smirnov test by setting the degree of confidence $(\alpha)$ at $5 \%$. This test is carried out on each variable provided that if individually each variable meets the normality assumption, then simultaneously these variables can also be declared to meet the normality assumption (Priyatno, 2010: 71). The test criteria by looking at the Kolmogorov-Smirnov test are as follows;

a) If the significance $>0.05$ then the data is normally distributed

b) If the significance $<0.05$ then the data is not normally distributed

\section{Multicollinearity Test}

Multicollinearity test is a test of assumptions to prove that the independent variables in a model are not correlated with one another. The existence of multicollinearity can cause the regression model obtained to be invalid for estimating the independent variable (Priyatno, 2010: 135). Symptoms of multicollinearity can also be detected by looking at the VIF (Variance Inflution Factor). Multicollinearity is considered not to occur if the VIF value is 5. 


\section{Heteroscedasticity Test}

Heteroscedasticity test means that the variance in the model is not the same, so the estimator obtained is inefficient. This is because the variance is not minimum. To determine whether there is heteroscedasticity or not, it can be done using the Levene test. According to Baroroh (2013: 25), heteroscedasticity testing using the levene test is done by creating a new column in the form of a group for all independent variables. Hesteroscedasticity is considered not to occur if the value is sig. levene test $>0.05$. According to Priyatno (2010: 93), if the results of absolute regression, all independent variables have an insignificant $t$ value, it can be said that the research model escapes the heteroscedasticity.

Hypothesis testing

T test (partial)

This analysis is used to prove whether the variables of work discipline and work motivation and job satisfaction are significant to the employee performance of ASTON Hotel Jember. The formula is (Priyatno, 2010: 142);

Hypothesis $\mathrm{t}$ test formulation;

1) Ho: bi $0, i=1,2,3$

$\mathrm{HO}$ is accepted and $\mathrm{Ha}$ is rejected, there is no partial (individual) influence between the independent variable $(\mathrm{X})$ on the dependent variable $(\mathrm{Y})$

2) Ha: bi $0, i=1,2,3$

$\mathrm{H} 0$ is rejected and $\mathrm{Ha}$ is accepted, there is a partial (individual) influence between the independent variable $(\mathrm{X})$ on the dependent variable $(\mathrm{Y})$

3) Level of significane $5 \%$.

4) Decision making criteria

a) If -table $\leq$ tcount $\leq$ ttabel: Ho is accepted, it means that there is no effect partially between the independent variables against the dependent variable

b) If $t$ count $\geq t$ table or $t$ count

$\geq \mathrm{t}$ table: Ho is rejected, it means that there is a partial influence between the independent variables on the dependent variable

F Test (Simultaneous)

The $F$ test is used to see the significance of the effect of the independent variables simultaneously (together) on the dependent variable (Priyatno, 2010: 144). In this study, the F 
test was used to see the significance of the effect of variables X1 and X2 simultaneously on variable $\mathrm{Y}$.

Decision-making criteria: Formulation of the F test hypothesis;

1) Ho: b1, b2 0

$\mathrm{HO}$ is rejected and $\mathrm{Ha}$ is accepted, there is a simultaneous influence between the independent variables $(\mathrm{X} 1$, and $\mathrm{X} 2$

) to the dependent variable (Y)

2) Ha: b1, b2 = 0

$\mathrm{HO}$ is accepted and $\mathrm{Ha}$ is rejected, there is no simultaneous effect between the independent variable (X1 and X2) on the dependent variable (Y)

3) Level of significane $5 \%$

4) Comparing the value of $F$ count with $F$ table of $F$ test criteria

a) If $\mathrm{F}$ count $\leq \mathrm{F}$ table then $\mathrm{Ho}$ is accepted, meaning there is no influence from the independent variable

b) If $F$ count $>F$ table then Ho is rejected, meaning that there is an effect of the independent variable simultaneously on the dependent variable

Coefficient of Determination

The coefficient of determination is data to determine how much is the percentage of direct influence of the independent variable that is closer to the dependent variable or it can be said that the use of the model is justified. The coefficient of determination (R2) can be obtained by a value to measure the amount of the contribution of several $\mathrm{X}$ variables to the fluctuating variation of variable $\mathrm{Y}$

\section{RESULT AND DISCUSSION}

Validity test

It is known that each indicator used in both the independent variable (work discipline, work motivation and job satisfaction) and the dependent variable (performance) has a calculated $r$ value which has a significance smaller than 0.05 . This means that the indicators used in this research variable are feasible or valid to be used as data collectors. 


\section{Reliability Test}

Based on Table 4.10, it can be concluded that all variables used in this study are reliable, because they have a Cronbach Alpha $(\alpha)$ value greater than 0.60. As required by Priyatno (2000: 2010: 97) that a construct is said to be unreliable if the Cronbach Alpha value is more than 0.60

Classic assumption test

Multicollinearity Test

One of the assumptions of the multiple linear regression model is that there is no perfect or imperfect correlation but it is very high on the independent variables. The multicollinearity test measures the level of closeness of the level of association (closeness) of the relationship or influence between independent variables by means of the correlation coefficient. Multicollinearity can be found by looking at the tolerance (a) and Variance Inflation Factor (VIF) values. The independent variable experiences multicollinearity if a count <a and VIF count $>$ VIF. The independent variable does not experience multicollinearity if a count $>$ a and VIF is more than <VIF. The cutoff value commonly used to indicate the presence of muliticollinearity is a tolerance value $<0.10$ or equal to the VIF value $>10$. The results of the multicollinearity test using the dependent variable are not correlated with itself. The meaning of correlation with oneself is that the value of the dependent variable is not related to the value of the variable itself, either the value of the previous variable or the value of the period afterwards (Santosa \& Ashari, 2005: 240).

\section{Result of Heterokedastisitas Test}

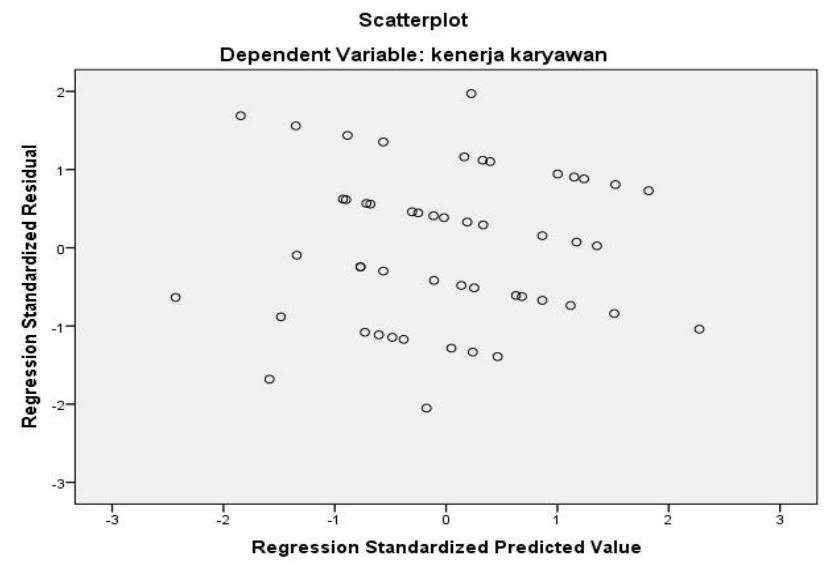




\section{Normality test}

The normality test tests the independent variable data $(\mathrm{X})$ and the dependent variable data $(\mathrm{Y})$ in the resulting regression equation, whether it is normally distributed or not normally distributed. Normality testing is done by testing a normal probability plot. Regression fulfills the normality assumption if the data spreads around the diagonal line and follows the direction of the diagonal line or the histogram graph shows a normal distribution pattern. It can be seen from the picture above that the plot / points spread out and follow the direction of the diagonal line, are around and along the 45 degree line, so it can be concluded that the research data is normally distributed.

Multiple Linear Regression Analysis

Multiple linear regression testing is useful for determining the level of influence of the independent variables (work discipline, work motivation and job satisfaction) on the dependent variable (performance). Based on the test, the results obtained can be presented in the following table.

Table 1. Regression Coefficient

\begin{tabular}{|c|c|c|c|c|c|c|c|}
\hline & & & Coefficients & & & & \\
\hline \multirow[b]{2}{*}{ Model } & \multicolumn{2}{|c|}{$\begin{array}{c}\text { Unstandardized } \\
\text { Coefficients }\end{array}$} & \multirow{2}{*}{$\begin{array}{c}\begin{array}{c}\text { Standardized } \\
\text { Coefficients }\end{array} \\
\text { Beta }\end{array}$} & \multirow[b]{2}{*}{$\mathrm{T}$} & \multirow[b]{2}{*}{ Sig. } & \multicolumn{2}{|c|}{$\begin{array}{c}95,0 \% \text { Confidence } \\
\text { Interval for B }\end{array}$} \\
\hline & B & $\begin{array}{l}\text { Std. } \\
\text { Error }\end{array}$ & & & & $\begin{array}{l}\text { Lower } \\
\text { Bound }\end{array}$ & $\begin{array}{l}\text { Upper } \\
\text { Bound }\end{array}$ \\
\hline 1 (Constant) & 10,917 & 2,028 & & 5,383 & ,000 & 6,834 & 14,999 \\
\hline disiplin kerja & ,255 & ,091 &, 371 & 2,795 & ,008 & 071 & ,439 \\
\hline Motivasi & ,210 & ,091 & ,300 & 2,304 & ,026 & ,026 & ,393 \\
\hline Kepuasan &,- 011 & 094 &,- 015 &,- 115 & ,909 &,- 201 & 179 \\
\hline
\end{tabular}

Based on these results, the multiple linear regression equation can be obtained as following:

$\mathrm{Y}=10.917+0.225 \mathrm{X} 1+0.210 \mathrm{X} 2-0.011 \mathrm{X} 3$

1. The constant result is $=10.917$. The results are significant and there is an influence on the performance of the employees of the Aston Jember Hotel. 
ABM : International Journal of Administration, Business and Management, Vol. 1 No. 1 November 2019

2. The results of the work discipline $\mathrm{X} 1=0.225$. The results are significant and there is an influence on employee performance at Hotel ASTON jember.

3. The results of the work motivation $X 2=0.210$. The results are significant and there is an influence on employee performance at Hotel ASTON jember

4. The results of job satisfaction $\mathrm{X} 3$ are $=-0.011$. The results are less significant and there is an influence on employee performance at Hotel ASTON jember

F Test Results

Simultaneous testing (Test F) This test aims to determine the effect of work discipline variables, work motivation and job satisfaction on performance together. Together the variables of work discipline, work motivation and job satisfaction will be proven to have a significant effect on performance if Fcount> Ftable. Conversely, if Fcount <Ftable, the variables of work discipline, work motivation and job satisfaction do not have a significant effect on performance. As for the value based on Table 4.13, it can be seen that Fcount> Ftable at $(5.008>2.81)$, then work discipline, work motivation and job satisfaction together have a positive and significant effect on performance at a significant level of $5 \%$, in this case Ha is accepted. . Thus, the hypothesis which states that work discipline, work motivation and job satisfaction simultaneously have a significant effect on employee performance at Hotel ASTON Jember is proven (Ha1 accepted).

T test results

This test is intended to determine the effect of each independent variable on the dependent variable. The trick is to compare the t-count statistical value with the table statistical value with a significant level $(\alpha)$ used, namely 5\%. Each independent variable is said to have a significant (real) effect. If $\mathrm{t}$ count is greater than $\mathrm{t}$ table, the variables of work discipline, work motivation and job satisfaction do not have a significant effect on performance. The magnitude of the $\mathrm{F}$ table value is at or if the probability $<5 \%(\alpha)$. The value of the table on the $\mathrm{t}$ table and the probability level is less than 5\%, then $\mathrm{HO}$ is rejected, meaning that partially the work motivation variable (X2) has a significant effect on performance (Y). 
ABM : International Journal of Administration, Business and Management, Vol. 1 No. 1 November 2019

The results of $t$ test calculations using the SPSS 16 for Windows program can be seen in the table. Based on this table, it can be seen that the influence of each independent variable on the dependent variable is as follows:

1. Effect of work discipline variable (X1) on performance (Y). The test results show that the tcount for the work discipline variable is smaller than the ttable, which is $2.795<2.81$ and the significance value is smaller than $\alpha$, namely $0.008<0.05$. Because $\mathrm{t}$ count is smaller than $\mathrm{t}$ table and the probability level is less than $5 \%$, then $\mathrm{HO}$ is rejected, meaning that partially the work discipline variable (X1) has a significant effect on performance (Y). So the hypothesis which states that work discipline partially has a significant effect on employee performance at ASTON Hotel shows that the tcount for the job satisfaction variable is smaller than the t-table, namely $0.115<2.81$ and the significance value is greater than $\alpha$, namely $0.909>0.05$. Because $\mathrm{t}$ count is smaller than t table and the probability level is greater than 5\%, then $\mathrm{H} 0$ is accepted, it means that partially the job satisfaction variable (X3) does not have a significant effect on performance $(\mathrm{Y})$. so that the hypothesis which states that job satisfaction partially has a significant effect on employee performance at Hotel ASTON Jember is proven (Ha4 rejected). 2. Effect of work motivation variable (X2) on performance (Y) The test results show that the tcount for the work motivation variable is smaller than the ttable, which is $2.304<2.81$ and the significance value is smaller than $\alpha$, namely $0.026>0.05$. Because tcount is smaller, it shows the tcount value for the job satisfaction variable is smaller than ttable, namely $0.115<2.81$ and the significance value is greater than $\alpha$, namely $0.909>0.05$.

3. The effect of the job satisfaction variable (X3) on performance (Y) The test results show that because tcount is smaller than ttable and the probability level is greater than 5\%, then $\mathrm{H} 0$ is accepted, meaning partially the job satisfaction variable (X3) has no significant effect. to performance (Y). so that the hypothesis which states that job satisfaction partially has a significant effect on employee performance at Hotel ASTON Jember is proven (Ha4 rejected). Analysis of the coefficient of determination

The value of the multiple coefficient of determination (R2) is intended to determine the size of the contribution of the independent variable to the dependent variable. If $\mathrm{R} 2=0$, then the model cannot influence or contribute to changes in the dependent variable. The fit of the model gets better the closer it is to unity. 
ABM : International Journal of Administration, Business and Management, Vol. 1 No. 1 November 2019

Based on the results of the analysis of the multiple coefficient of determination (R2) of 0.246 , this means that $24.6 \%$ of changes in performance are influenced by the variables of work discipline, work motivation and job satisfaction while the remaining $75.4 \%$ is caused by other factors not included in the regression equation made.

\section{DISCUSSION}

\section{The Effect of Work Discipline on Employee Performance}

The results showed that work discipline has a significant effect on employee performance. Because t count is smaller than t table and the probability level is less than $5 \%$, then $\mathrm{H} 0$ is rejected, meaning that partially the work discipline variable (X1) has a significant effect on performance $(\mathrm{Y})$. so the hypothesis which states that work discipline partially has a significant effect on employee performance at Hotel ASTON Jember is proven (Ha2 accepted). This result is in accordance with research conducted by Regina (2010) which states that work discipline partially has a significant effect on employee performance. This is in accordance with the theory of Hasibuan (2008: 143), work discipline is the awareness and willingness of a person to obey all company regulations and applicable norms. When an employee has high awareness and willingness to obey all existing regulations, it is undeniable that employee performance will be optimal.

\section{The Effect of Work Motivation on Employee Performance}

The results showed that work motivation has a significant effect on employee performance. Because t count is smaller than t table and the probability level is less than $5 \%$, then $\mathrm{H} 0$ is rejected, meaning that partially the work motivation variable (X2) has a significant effect on performance (Y). So the hypothesis which states that work motivation partially has a significant effect on employee performance at PT Hotel ASTON Jember is proven (Ha3 accepted). These results are consistent with research conducted by Isabelle (2014) which states that work motivation partially has a significant effect on employee performance. This is in accordance with the theory of Hasibuan (2010: 95), motivation is the provision of a driving force that creates a person's enthusiasm for work, so that they are willing to work together, work effectively and are integrated with all their efforts to achieve satisfaction at work. By giving motivation, it means giving incentive to employees so that they are more enthusiastic and active in working with all their abilities, so that employee performance can increase optimally. 


\section{The Effect of Job Satisfaction on Employee Performance}

The results showed that job satisfaction had an insignificant effect on employee performance. Because $\mathrm{t}$ count is smaller than $\mathrm{t}$ table and the probability level is greater than $5 \%$, then $\mathrm{H} 0$ is accepted, it means that partially the job satisfaction variable (X3) does not have a significant effect on performance (Y). So that the hypothesis which states that job satisfaction partially has a significant effect on employee performance at Hotel ASTON Jember is proven (Ha4 rejected). This result is not in accordance with previous research which states that job satisfaction partially has a significant effect on employee performance. This is not in accordance with what is in Handoko's theory (2000: 193). Job satisfaction is a pleasant or unpleasant emotional state in how employees perceive their work. Job satisfaction reflects a person's feelings about his job.

4. Simultaneous Influence of Discipline, Motivation and Job Satisfaction on Employee Performance

The results showed that work discipline, work motivation and job satisfaction simultaneously have a significant effect on performance. Thus, the hypothesis which states work discipline, work motivation and job satisfaction simultaneously has a significant effect on employee performance at Hotel ASTON Jember is proven (H1 accepted). In a work discipline organization, work motivation and job satisfaction are very influential on employee performance. Good work discipline will improve employee performance. With work discipline, employees are required to obey all existing regulations in the company such as going to work and coming home from work to be on schedule so that the performance generated by employees will be optimal and maximum.

\section{CONCLUSION}

Based on the results of the research and discussion described in the previous chapter, the conclusion that can be drawn from this study is that motivation work discipline partially affects performance. However, job satisfaction is not the case. While all variables together affect the performance of aston hotel employees. Discipline, motivation and satisfaction simultaneously and significantly influence employee performance at Hotel ASTON Jember 


\section{IMPLICATIONS}

Discipline, motivation and job satisfaction can affect employee performance partially or simultaneously, if work discipline is good then employee performance will also be good, and vice versa, if work motivation is good then employee performance will also be good, and vice versa, job satisfaction is formed in in the company also affects employee performance, if job satisfaction is good then employee performance will also be good, and vice versa. If the company wants to improve employee performance, the company should improve all things that can affect the increase in employee performance without affecting the discipline, motivation and job satisfaction that already exists in the company.

\section{REFERENCES}

Regina, 2010. “Pengaruh Gaya Kepemimpinan, Motivasi kerja dan Disiplin Kerja terhadap Kinerja Karyawan PT. Sinar Santoso Perkara Banjarnegara”:Universitas Diponegoro

Grifin, R.W. 2003. Manajemen. Jakarta. Erlangga. Handoko, T.H. 2001. Manajemen Personalia dan Sumber Daya Manusia. Yogyakarta: BPFE Press

Hasibuan, M. 2003. Organisasi dan Motivasi. Dasar Peningkatan Produktivitas. Jakarta: Bumi Aksara

Mangkunegara, Anwar P. 2006. Evaluasi Kinerja Sumber Daya Manusia. Bandung: PT. Reflika Aditama.

Harlie. 2010. "Pengaruh Disiplin Kerja, Motivasi kerja dan Pengembangan Karir terhadap Kinerja Pegawai PNS pada Pemerintah Kabupaten Tebalong Kalimantan Selatan”.STIA Tabalong Kalimantan Selatan

Maslow, A. 1984. Motivasi dan kepribadian. Jakarta: Pustaka Binangan Prestindo.

Ketut.ayu. 2014. "Pengaruh Kompensasi dan Motivasi terhadap Kepuasan dan Kinerja Karyawan pada Hotel Bakung's beach cottages Kuta-Bali’.Fakultas Ekonomi, Universitas Udayana Bali.

Mathis, Robert L. Dan Jackson. Jhon H. 2006. Human Resource Management 